\title{
ADSORPTIVE REMOVAL BEHAVIOUR OF PROCION MX-R DYE FROM SRDW BY CHITOSAN
}

\author{
GÖNEN, F. ${ }^{1 *}-$ ÖNALAN, F. ${ }^{1}$ \\ ${ }^{I}$ Mersin University, Chemical Engineering Department, 33343, Çiftlikköy/Mersin-Turkey \\ *Corresponding Author \\ e-mail: gonenf74@gmail.com \\ (Received $7^{\text {th }}$ Jul 2015; accepted $17^{\text {th }}$ Dec 2015)
}

\begin{abstract}
In this study, the application of chitosan for the removal of Procion MX-R dye from synthetic reactive dye wastewater (SRDW) was investigated under ambient conditions. The optimum conditions for the adsorption of Procion MX-R dye onto the adsorbent was found to be: $\mathrm{pH}$ (4.0), adsorbent dose (1.0 g), temperature of $35^{\circ} \mathrm{C}$ for an initial Procion MX-R dye concentration of $100 \mathrm{mg} / \mathrm{L}$. Langmuir and Freundlich adsorption isotherm models were applied which fitted the data with $R^{2}$ value of 0.990 . The adsorption of Procion MX-R on chitosan was confirmed by SEM study, as it showed the change in characterization before and after adsorption. The kinetic results showed that the rate of dye adsorption follows pseudo-second-order model for the dye concentration range studied in the present case. In addition, various thermodynamic parameters, such as standard Gibbs free energy $\left(\Delta G^{\circ}\right)$, standard enthalpy $\left(\Delta \mathrm{H}^{\circ}\right)$ and standard entropy $\left(\Delta S^{\circ}\right)$ have been calculated. It has been found that the chitosan/dye interaction was feasible, spontaneous and exothermic in nature. As a result, chitosan have been shown to be a very efficient and low-cost adsorbent, and a promising alternative for eliminating dyes from industrial wastewaters.
\end{abstract}

Keywords: adsorption, chitosan, kinetic, Procion MX-R, thermodynamic, wastewater

\section{Introduction}

The main sources of water contamination are the rapid growth of the world population, industrialization, unplanned urbanization, agricultural activities, as well as the excessive use of chemicals and other environmental and global changes (Gupta, 2009). Textile, paper, printing, leather, food and plastic industries are major industrial wastewater sources. The presence of dyes in textile wastewater is an important environmental problem because of their high visibility, resistance and toxic impact (Ali et al., 2009). The colored dye effluents are considered to be highly toxic to the aquatic biota and can reduce photosynthetic activities in aquatic environments by preventing the penetration of light and oxygen (Crini, 2006). Most of dyes have non-biodegradable structures that remain stable under different conditions (Buthelezi et al., 2012). In addition, dyes have hazardous and toxic effects on humans as they are associated with cancer, jaundice, tumors, skin irritation, allergies, heart defects and mutations (Alver and Metin, 2012; Hariharasuthan et al., 2013). It is essential to select the most suitable treatment method for the removal of dye from wastewater and to improve the quality of treated wastewater discharged into the environment. There are different treatment methods are used for color removal from the industrial effluents to reduce their impact on the environment. These techniques include chemical oxidation, foam flotation, electrolysis, biodegradation, adsorption, chemical coagulation and photocatalysis (McClung and Lemley 1994; Lin and Lo 1996; Bousher et al. 1997; Oakes and Gratton 1998; Poulios and Aetopoulou 1999; Papic et al. 2000; Lopez and Gutierrez 2006; Tahir and Rauf 2006; Fu et al. 2007). However, each of these method has several limitations such as high capital or operating costs, low efficiency and generation of excess. So, some of these methods are inappropriate for small-scale industrial applications. (Kobya et al., 2005). Adsorption is a phenomenon with common mechanism for organic and inorganic pollutants removal. It is one of the most effective method in the other 
methods used. Because it is rapid, convenient and inscrutable to toxic contaminants. It is also effective, inexpensive, ecofriendly and rather simple in terms of design and operation of the treatment unit (Abbasi and Alikarami, 2012; Yadla et al., 2012; McKay, 1982). When a solution containing adsorptive solute comes into contact with a solid with a highly porous structure, intermolecular attraction forces cause some of the solute molecules from the solution to be concentrated at the structure. The solute accumulated in the structure is called adsorbate, while the structure itself is called adsorbent. The nature and type is one of the most effective method used of adsorbent used in adsorption process effects removal efficiency. In order to remove dye from wastewater, both organic and inorganic materials could be used as adsorbents. Granular activated carbon is the most preferable adsorbent and has been used successfully in adsorption processes (McKay, 1982), but is expensive in comparison with other sorbents. Consequently, many investigators have studied alternatively the possibility of using low cost substances, such as: chitin (McKay et al., 1982), chitosan (Wong et al., 2008), perlite (Doğan and Alkan, 2003), natural clay (El-Geundi, 1991; El-Geundi 1993), bagasse pith (McKay et al., 1987; McKay et al., 1988; Nassar et al., 1996), coal fly ash (Ho and McKay, 1999), boiler bottom ash (Mall and Upadhyay, 1995), bagasse fly ash (Mall and Upadhyay, 1998; Swamy et al., 1998), wood (Poots et al., 1978; Asfour et al., 1985; Magdy, 1996; Garg and Kumar, 2003), rice husk (Malik, 2003), peat (Poots et al., 1976; Allen, 1987; Allen et al., 1989), maize cob (El-Geundi, 1990), bean waste (Yehia and Abd El-Hakim, 1997), banana pith (Namasivayam and Kanchana, 1992; Namasivayam et al., 1993; Namasivayam et al., 1998), coir pith (Namasivayam et al., 2001; Namasivayam and Kavitha, 2002), red mud (Namasivayam and Arasi, 1997), orange peel (Namasivayam et al., 1996), biogas waste slurry (Namasivayam and Yamuna, 1992; Namasivayam and Yamuna, 1992) as adsorbents for the removal of dyes from wastewaters. Pollard et al. (1992), Mall et al. (1996), and Bailey et al. (1999) have presented a critical review of low cost adsorbents for waste and wastewater treatment.

Chitosan is generously available low-cost bio-polymer for dye removal that can be obtained from the seafood processing industry, mainly shells of crabs, shrimp, prawns, and krill (Fernanda et al., 2002). If it is compared with other commercial adsorbents, it has received a lot of focus due to its specific properties such as cationicity, high adsorption capacity, macromolecular structure, abundance and low price (Muzzarelli et al., 2012).

The dye Procion Blue MX-R is a commercially important anthraquinone dye largely employed for cotton dyeing. Relative to the dye toxicity, a rodent must be administered $100 \mathrm{mg}$ into the eye over a $24 \mathrm{~h}$ period for a moderate reaction and the oral $\mathrm{LD}_{50}$ for rodents was reported as $8980 \mathrm{mg}$ dye $/ \mathrm{kg}$ for $\mathrm{PB}$ dye (Epolito, 2005). The estimated $\mathrm{LC}_{50}$ for fish over 14 days was estimated as $1500 \mathrm{mg} \mathrm{L}^{-1}$ for $\mathrm{PB}$ dye Due to its high toxicity, it is necessary to remove this dye from aqueous effluents.

Therefore, the objective of this research is to study the feasibility of using chitosan as an adsorbent for the removal of Procion dye from synthetic reactive dye wastewater. The influences of $\mathrm{pH}$, initial dye concentration, temperature, and adsorbent dosage on the adsorption of Procion MX-R were investigated in order to determine optimum conditions for the maximum removal of dyestuff by chitosan from aqueous solution. Both Langmuir and Freundlich adsorption isotherms were applied to the experimental results to derive the adsorption parameters for Procion MX-R dye onto chitosan sorbent at different temperatures. The adsorption rates were determined quantitatively by the pseudo first, second-order and the intraparticle diffusion model in order to investigate the adsorption mechanism. This article also critically analyses thermodynamic parameters for the Procion MX-R dye-chitosan system at three different temperatures. A compilation of relevant published data with respect to adsorption kinetics, isotherm models, thermodynamics and adsorption capacity under various process conditions along with important findings is offered here. 


\section{Experiment}

\section{Adsorbent}

Samples of chitosan flakes with a deacetylation percentage of approximately $85 \%$ extracted from snow crab shell were purchased from Sigma-Aldrich Company and used as adsorbate in the experiments. Some essential properties of chitosan are given in Table 1 (Uzun and Güzel, 2004). The chemical structure of chitosan is shown in Fig. 1. All raw chitosan was sieved into discrete particle size range from 0 to $300 \mu \mathrm{m}$.

Table 1. Some essential properties of chitosan

\begin{tabular}{ll}
\hline Deacetylation degree & Minimum $85 \%$ \\
\hline Formula weight & $810,000 \mathrm{~g} \mathrm{~mol}^{-1}$ \\
BET surface area & $0.65 \mathrm{~m}^{2} \mathrm{~g}^{-1}$ \\
Density & $0.15-0.30 \mathrm{gm} \mathrm{L}^{-1}$ \\
pKa & 6.3 \\
Colour & Light yellow \\
\hline
\end{tabular}

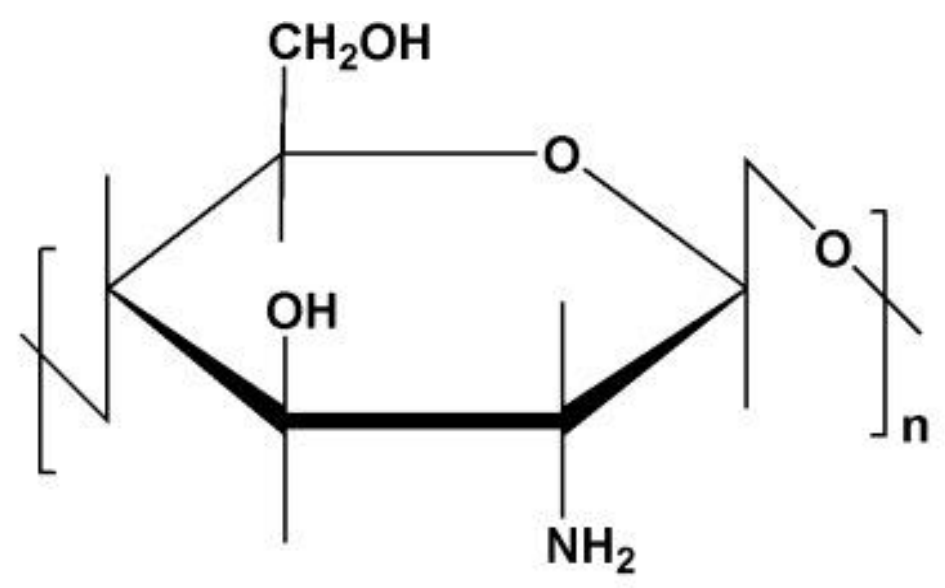

Figure. 1. The molecular structure of chitosan.

\section{Chemicals}

In this study, Procion MX-R as adsorbate was used. Some essential properties of Procion MX-R are given in Table 2. The chemical structure of Procion MX-R is shown in Fig. 1. Procion MX-R dye solutions used in the experiments were prepared by diluting $1.0 \mathrm{~g} \mathrm{~L}^{-1}$ of stock solution of dye which was obtained by dissolving weighed quantity of Procion MX-R in $1 \mathrm{~L}$ of double-distilled water. The range of concentrations of prepared dye solutions was between 25 and $150 \mathrm{mg} \mathrm{L}^{-1}$. The $\mathrm{pH}$ of each solution was adjusted to the required value with diluted or concentrated $\mathrm{H}_{2} \mathrm{SO}_{4}$ and $\mathrm{NaOH}$ solutions before mixing the adsorbent material (chitosan). All chemicals were of reagent grade. Doubly distilled water were used to prepare all solutions. 
Table 2. Some essential properties of Procion blue MX-R

\begin{tabular}{l|l}
\hline Name: & Procion blue MX-R \\
\hline CAS: & $13324-20-4$ \\
Synonyms & Blue MR, Reactive Blue 4; Ambifix Blue CR, Brill.Blue X- \\
& BR, Reactive Blue MR, Ostazin Blue S-R, Viactive Blue MR \\
Molecular Formula & $\mathrm{C}_{23} \mathrm{H}_{14} \mathrm{Cl}_{2} \mathrm{~N}_{6} \mathrm{O}_{8} \mathrm{~S}_{2}$ \\
Molecular Weight & 637.4287 \\
Density & $1.86 \mathrm{~g} / \mathrm{cm}^{3}$ \\
Refractive index & 1.774 \\
\hline
\end{tabular}<smiles>Nc1c(S(=O)(=O)O)cc(Nc2ccc(S(=O)(=O)O)c(Nc3nc(Cl)nc(Cl)n3)c2)c2c1C(=O)c1ccccc1C2=O</smiles>

Figure. 2. The molecular structure of Procion M-XR.

\section{Adsorption Studies}

The adsorption experiments were carried out in the batch mode for the measurement of adsorption capabilities. The bottles with $250 \mathrm{~mL}$ capacity were filled with $150 \mathrm{~mL}$ of the SRDW at desired $\mathrm{pH}$, concentration, and temperature. During the adsorption studies, $0.15 \mathrm{~g}$ of adsorbent was treated with $150 \mathrm{ml}$ of Procion MX-R dye solution. The flasks were agitated at a $150 \mathrm{rpm}$ constant shaking rate for $3 \mathrm{~h}$. The samples were withdrawn from the shaker at predetermined time intervals ensure equilibrium was reached. Samples $(5 \mathrm{~mL})$ were taken before mixing the adsorbent and dye bearing solution at pre-determined time intervals.

After contact period for adsorption, supernatants were separated from the solid phase by centrifugation at $4000 \mathrm{rpm}$ for $5 \mathrm{~min}$. All the experiments were carried out in duplicates to avoid any discrepancy in experimental results and the average values were used for further data evaluation.

Data analysis of adsorption process has great importance for developing equilibrium, kinetic and thermodynamic equations that can be used for design purposes. The adsorption capacity of Procion MX-R dye adsorbed per gram adsorbent $\left(\mathrm{mg} \mathrm{g}^{-1}\right)$ was calculated using the following equation:

$$
\mathrm{q}_{\mathrm{e}}=\left(\mathrm{C}_{0}-\mathrm{C}_{\mathrm{e}}\right) \mathrm{V} / \mathrm{m}
$$

where $\mathrm{q}_{\mathrm{e}}$ is the equilibrium concentration of Procion MX-R on the adsorbent ( $\left.\mathrm{mg} \mathrm{g}^{-1}\right), \mathrm{C}_{0}$ is the initial concentration of the Procion MX-R solution $\left(\mathrm{mg} \mathrm{L}^{-1}\right), \mathrm{C}_{\mathrm{e}}$ is the equilibrium 
concentration of the Procion MX-R solution $\left(\mathrm{mg} \mathrm{L}^{-1}\right), \mathrm{m}$ is the mass of adsorbent $(\mathrm{g}), \mathrm{V}$ is the volume of Procion MX-R solution (L).

\section{Analysis of Procion MX-R}

The colorimetric method was used to determine the unadsorbed Procion MX-R dye in the adsorption medium by using a spectrophotometer (Chebios UV-VIS double beam spectrophotometer). Absorbance values were measured at a wavelength of $610 \mathrm{~nm}$.

\section{Results and Discussion}

\section{pH Effect}

$\mathrm{pH}$ is one of the most important process parameters since the $\mathrm{pH}$ of the adsorption medium will change the magnitude of the electrostatic charges that are imparted by ionized dye molecules. As a result the rate of adsorption will vary with $\mathrm{pH}$ of an aqueous medium. Herein, the experiments were carried out in the $\mathrm{pH}$ range between 2 and 6 for initial Procion MX-R concentration of $100 \mathrm{mg} \mathrm{L}^{-1}$ at $25^{\circ} \mathrm{C}$ with a $1.0 \mathrm{~g} \mathrm{~L}^{-1}$ adsorbent dose for $180 \mathrm{~min}$ contact time. High $\mathrm{pH}$ values were not studied to avoid precipitation. The effect of $\mathrm{pH}$ on the removal of Procion MX-R is shown in Fig. 3.

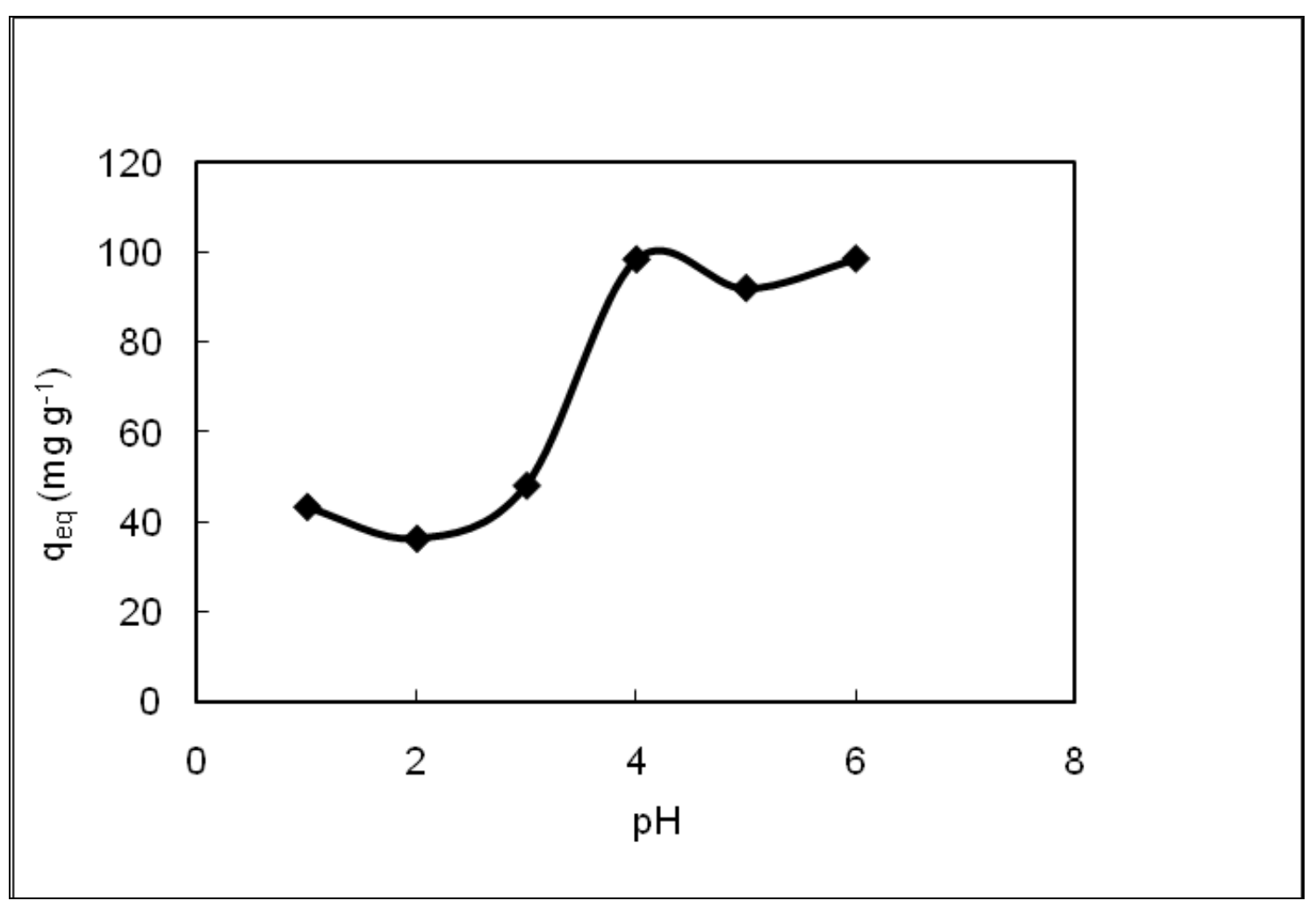

Figure. 3. The effect of initial $p H$ on the adsorption of Procion Blue MX-R by chitosan $\left(T: 25^{\circ} \mathrm{C}\right.$, $C_{0}: 100 \mathrm{mg} \mathrm{L}^{-1}, X: 1.0 \mathrm{~g} \mathrm{~L}^{-1}$, Agitation rate: $150 \mathrm{rpm}$ ).

It is clear from Fig. 3 that the adsorption of the Procion MX-R increases with increasing initial $\mathrm{pH}$ from 2 to 4 and declined slightly with further increase in $\mathrm{pH}$. For example, while the maximum dye removal by Procion MX-R is $36.40 \mathrm{mg} \mathrm{g}^{-1}(41.0 \%)$ at $\mathrm{pH} 2$, it is found as 98.51 $\mathrm{mg} \mathrm{g}^{-1}(99.60 \%)$ at $\mathrm{pH}$ 4. The fact that the maximum dye removal is more at higher $\mathrm{pH}$ indicates that the surface of sorbent has became more negatively, and therefore the interaction 
between negatively charged sorbent and positively charged Procion MX-R molecules is greater. Also, lower dye removal at acidic $\mathrm{pH}$ is probably due to the presence of excess $\mathrm{H}^{+}$ions competing with positively charged Procion MX-R molecules for the sorption sites of sorbents. In the literature, similar results were reported for Methylene Blue sorption onto jackfruit peel (Hameed 2009) and wheat shells (Bulut and Aydin 2006).

As seen from the Fig. 3, the adsorption of Procion MX-R was maximum $\left(\mathrm{q}_{\mathrm{eq}}=98.51 \mathrm{mg} \mathrm{g}^{-1}\right)$ at $\mathrm{pH} 4.0$ so the working $\mathrm{pH}$ value for Procion MX-R adsorption was determined as 4.0 and the other adsorption experiments were performed at this $\mathrm{pH}$ value.

\section{Temperature Effect}

Adsorption process is significantly affected by the temperature since the change in temperature will cause changes the equilibrium capacity of the adsorbent for adsorption of particular adsorbate (Al-Qodah, 2000).

Fig. 4 presents that the effect of temperature on the adsorption of the chitosan at $\mathrm{pH} 4$ and $100 \mathrm{mg} \mathrm{L}^{-1}$ initial dye concentration. The increasing temperature from 25 to $35^{\circ} \mathrm{C}$ increased the adsorption capacity of chitosan. As it seen from Fig. 4, equilibrium adsorption capacity was $98.95(99.54 \%)$ and $101.19(99.26 \%) \mathrm{mg} \mathrm{g}^{-1}$ for 25 and $35^{\circ} \mathrm{C}$, respectively. When the temperature increases from $35^{\circ} \mathrm{C}$ to $45^{\circ} \mathrm{C}$ the values of unit sorption onto chitosan decrease from 101.19 to $96.27(97.14 \%) \mathrm{mg} \mathrm{g}^{-1}$. Therefore the optimum temperature for Procion MX-R adsorption was determined as $35^{\circ} \mathrm{C}$. This indicates that adsorption of Procion MX-R on to chitosan is controlled by exothermic processes so the adsorption of dye by chitosan may involve mainly physical sorption. The decrease in adsorption capacity of chitosan at higher temperature may be attributed to the deactivation of the adsorbent surface. Experimental results proved that temperature plays an important role on the dye adsorption capacity of chitosan.

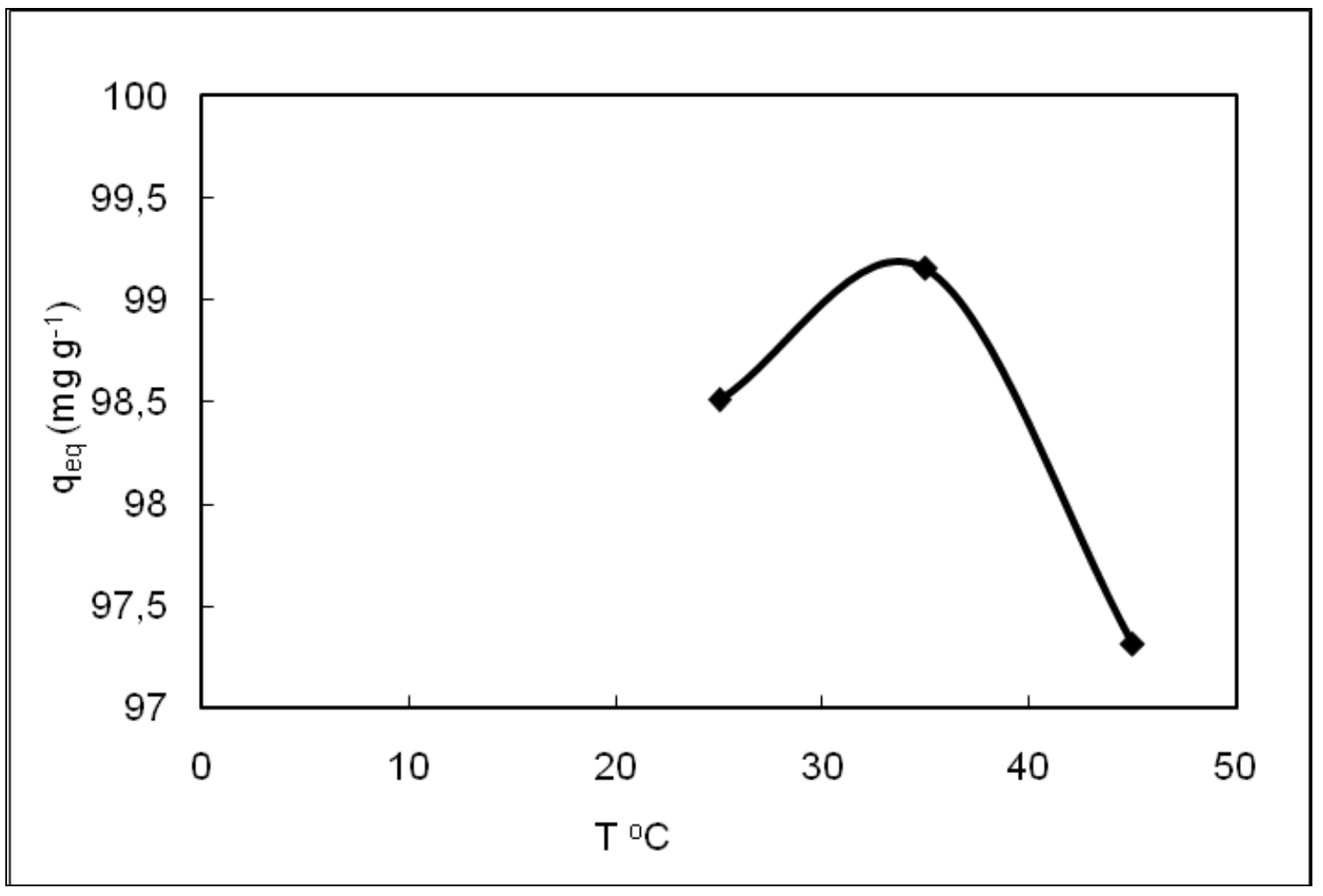

Figure. 4. The effect of temperature on the adsorption of Procion Blue MX-R by chitosan ( $\mathrm{pH}=4, \mathrm{C}_{0}: 100 \mathrm{mg} \mathrm{L}^{-1}, \mathrm{X}: 1.0 \mathrm{~g} \mathrm{~L}^{-1}$, Agitation rate: $150 \mathrm{rpm}$ ). 


\section{Adsorbent Dose}

The removal of Procion MX-R by chitosan was studied at different adsorbent doses $(0.50$, 1.0, 2.0, 3.0 and $4.0 \mathrm{~g} \mathrm{~L}^{-1}$ ) for the initial dye concentration of $100 \mathrm{mg} \mathrm{L}^{-1}$ at $25^{\circ} \mathrm{C}$ and $\mathrm{pH} 4.0$. It is evident from Table 3 that dye adsorption increases in an adsorbent dose. When the sorbent dose increases from 0.5 to $4.0 \mathrm{~g}$, the percent dye removal by Procion MX-R increases from $98.78 \%$ to $99.24 \%$ at an equilibrium time of $20 \mathrm{~min}$.

This phenomenon can be simply explained by the existence of the increased sorbent surface area and availability of more sorption sites (Garg et al., 2004). On the other side, the amount of solute sorbed per unit sorbent decreases with an increase in sorbent dose. For example, when the sorbent dosage increases from 0.5 to $4.0 \mathrm{~g}$, the values of unit sorption onto chitosan decrease from 193.43 to $24.47 \mathrm{mg} \mathrm{g}^{-1}$. This may be because of overlapping of adsorption sites as a result of overcrowding of adsorbent particles (Namasivayam et al., 1998).

Table. 3. The effect of adsorbent dose on equilibrium uptake capacities and adsorption yields of Procion Blue MX-R by chitosan

\begin{tabular}{lccccc}
\hline $\mathrm{Xo}\left(\mathrm{g} \mathrm{L}^{-1}\right)$ & 0.5 & 1.0 & 2.0 & 3.0 & 4.0 \\
\hline $\mathrm{q}_{\mathrm{eq}}\left(\mathrm{mg} \mathrm{g}^{-1}\right)$ & 193.43 & 98.95 & 49.32 & 31.94 & 24.47 \\
$\mathrm{Ad} \%$ & 98.78 & 99.55 & 99.09 & 98.9 & 99.24 \\
\hline
\end{tabular}

\section{Initial Procion MX-R Concentration Effect}

Only a fixed amount of adsorbate can adsorbed by a given mass of adsorbent. In adsorption process, increasing initial dye concentration increases the number of interactions between dye anions and sorbent, which enhances the sorption process. Hence a higher initial concentration of dye will increase the adsorption rate. As a result, the initial concentration of adsorbate solution is very important in adsorption processes. The effect of initial dye concentration on the dye adsorption capacities of chitosan was investigated between 25 and $150 \mathrm{mg} \mathrm{L}^{-1}$ at three different temperatures and the results are presented in Table 4. If it notices to Table 4, the equilibrium sorption capacity of chitosan for Procion MX-R dye increased notably with increasing initial dye concentration up to $150 \mathrm{mg} \mathrm{L}^{-1}$, and decreased with increasing temperature up to $45^{\circ} \mathrm{C}$. However, it is evident that higher percentage of dye was removed with decrease in initial dye concentration for all temperatures. For example, when the initial Procion MX-R concentration increases from 25 to $150 \mathrm{mg} \mathrm{L}^{-1}$, the equilibrium sorption capacities of chitosan increase from $24.77(97.63 \%)$ to $135.97 \mathrm{mg} \mathrm{g}^{-1}(95.69 \%)$ at $25^{\circ} \mathrm{C}$. From the same table, it is seen that the adsorption capasity decreased from $147.16(94.99 \%) \mathrm{mg} \mathrm{g}^{-1}$ to $27.91(99.46 \%) \mathrm{mg} \mathrm{g}^{-1}$ with the change in temperature from 45 to $25^{\circ} \mathrm{C}$.

Fig. 5 shows the adsorption curves of Procion MX-R dye at $25{ }^{\circ} \mathrm{C}$ by plotting the dye uptake capacity q versus time for $25-150 \mathrm{mg} \mathrm{L}^{-1}$ of initial dye concentrations for the first 180 min of adsorption. For the studied concentrations, the amount of dye increased linearly with time at the beginning, then non-linearly at a slower rate and finally attained saturation called the equilibrium time. 
Table 4. Effect of initial Procion Blue MX-R concentration and temperature on the equilibrium uptake capacities and adsorption yields of dye by chitosan

\begin{tabular}{ccccccccc}
\hline \multicolumn{3}{c}{$25{ }^{\circ} \mathrm{C}$} & \multicolumn{3}{c}{$35^{\circ} \mathrm{C}$} \\
$\mathrm{Co}\left(\mathrm{mg} \mathrm{L}^{-1}\right)$ & $\mathrm{q}_{\mathrm{eq}}\left(\mathrm{mg} \mathrm{g}^{-1}\right)$ & $\%$ Ad & $\mathrm{Co}\left(\mathrm{mg} \mathrm{L}^{-1}\right)$ & $\mathrm{q}_{\mathrm{eq}}\left(\mathrm{mg} \mathrm{g}^{-1}\right)$ & $\% \mathrm{Ad}$ & $\mathrm{Co}\left(\mathrm{mg} \mathrm{L}^{-1}\right)$ & $\mathrm{q}_{\mathrm{eq}}\left(\mathrm{mg} \mathrm{g}^{-1}\right)$ & $\% \mathrm{Ad}$ \\
25.37 & 24.77 & 97.63 & 27.61 & 27.16 & 98.37 & 28.06 & 27.91 & 99.46 \\
49.1 & 47.61 & 96.96 & 53.43 & 52.53 & 98.31 & 54.77 & 53.88 & 98.37 \\
75.97 & 75.37 & 99.21 & 83.13 & 82.23 & 98.91 & 78.21 & 77.01 & 98.46 \\
99.4 & 98.95 & 99.54 & 101.94 & 101.19 & 99.26 & 99.1 & 96.27 & 97.14 \\
119.4 & 118.5 & 99.24 & 134.62 & 132.38 & 98.33 & 128.65 & 124.62 & 96.86 \\
142.09 & 135.97 & 95.69 & 158.21 & 156.71 & 99.05 & 154.92 & 147.16 & 94.99 \\
\hline
\end{tabular}

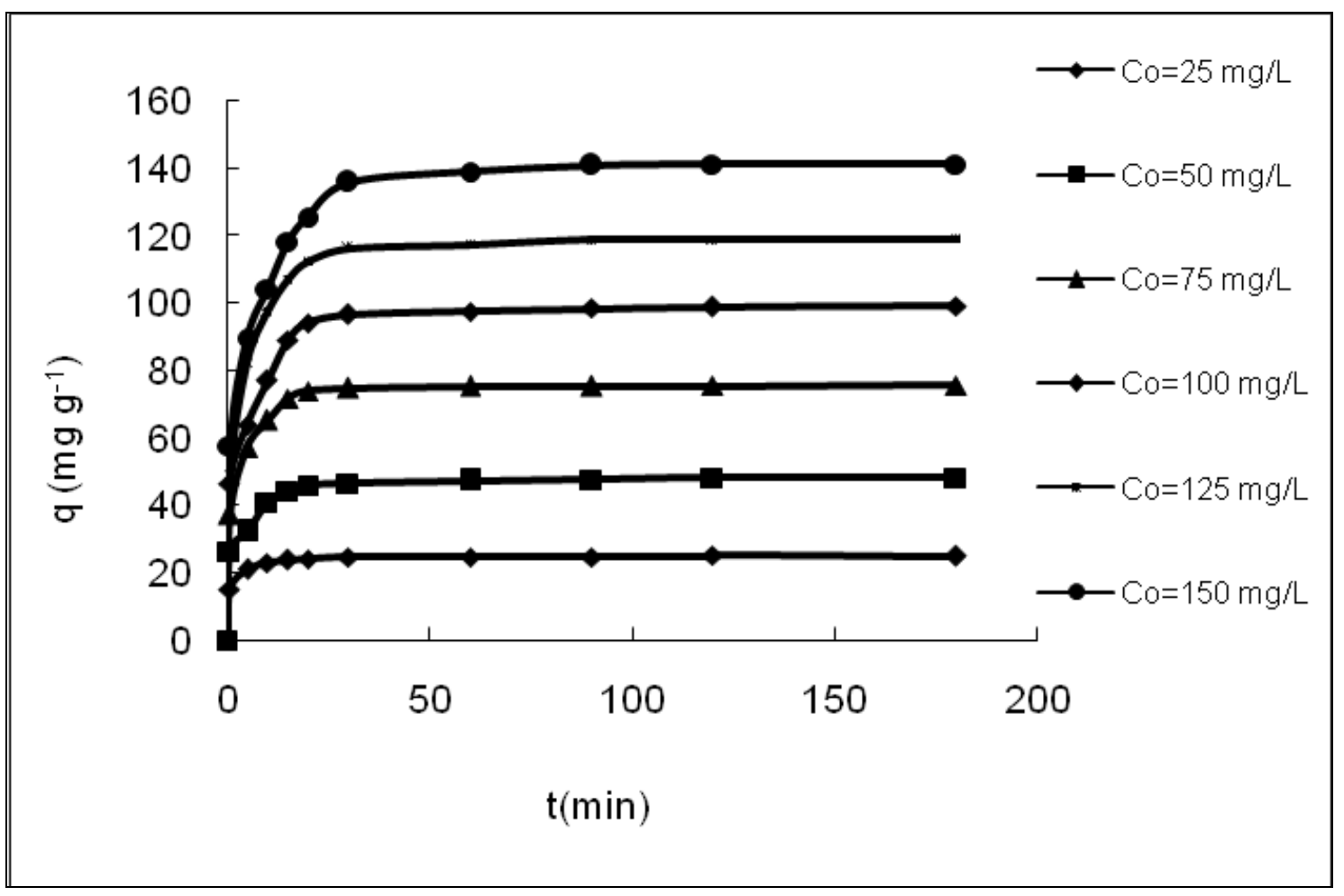

Figure. 5. The adsorption curves of Procion Blue MX-R dye obtained at 25 and $150 \mathrm{mg}$ $L^{-1}$ initial dye concentrations ( $\mathrm{pH}$ 4.0, X:1.0 $\mathrm{g} \mathrm{L^{-1 }}, T=25^{\circ} \mathrm{C}$, agitation rate: $150 \mathrm{rpm}$ ).

As it seen from Fig. 5 and Table 4, adsorption capacity was mainly dependent on initial dye concentration besides time and temperature parameters.

\section{Adsorption Isotherms}

To show how the adsorption molecules are distributed between the liquid phase and the solid phase when an equilibrium state is established in the adsorption process, it is important to find 
out the most appropriate correlation for the equilibrium curves. The most important step is to analyze the isotherm data by fitting them to different isotherm models to find the suitable model that can be used for design purpose. There are several isotherm equations are available for analyzing experimental adsorption equilibrium data in the literature. In this study, the equilibrium experimental data for adsorbed Procion MX-R on chitosan sample were analyzed using Langmuir and Freundlich models. These isotherms are as follows:

Langmuir isotherm model (Langmuir, 1918):

$$
\mathrm{C}_{\mathrm{e}} / \mathrm{q}_{\mathrm{e}}=1 / \mathrm{Q}_{\mathrm{o}} \mathrm{b}+\mathrm{C}_{\mathrm{e}} / \mathrm{Q}_{\mathrm{o}}
$$

where $\mathrm{Q}^{\mathrm{o}}$ and $\mathrm{b}$ are Langmuir constants, which indicate the sorption capacity $\left(\mathrm{mg} \mathrm{g}^{-1}\right)$ and energy of sorption, respectively.

Freundlich isotherm model (Freundlich, 1906):

$$
\log \mathrm{q}_{\mathrm{e}}=\log \mathrm{K}+(1 / \mathrm{n}) \log \mathrm{C}_{\mathrm{e}}
$$

where $\mathrm{K}$ and $\mathrm{n}$ are Freundlich constants related to the adsorption capacity and adsorption intensity, respectively.

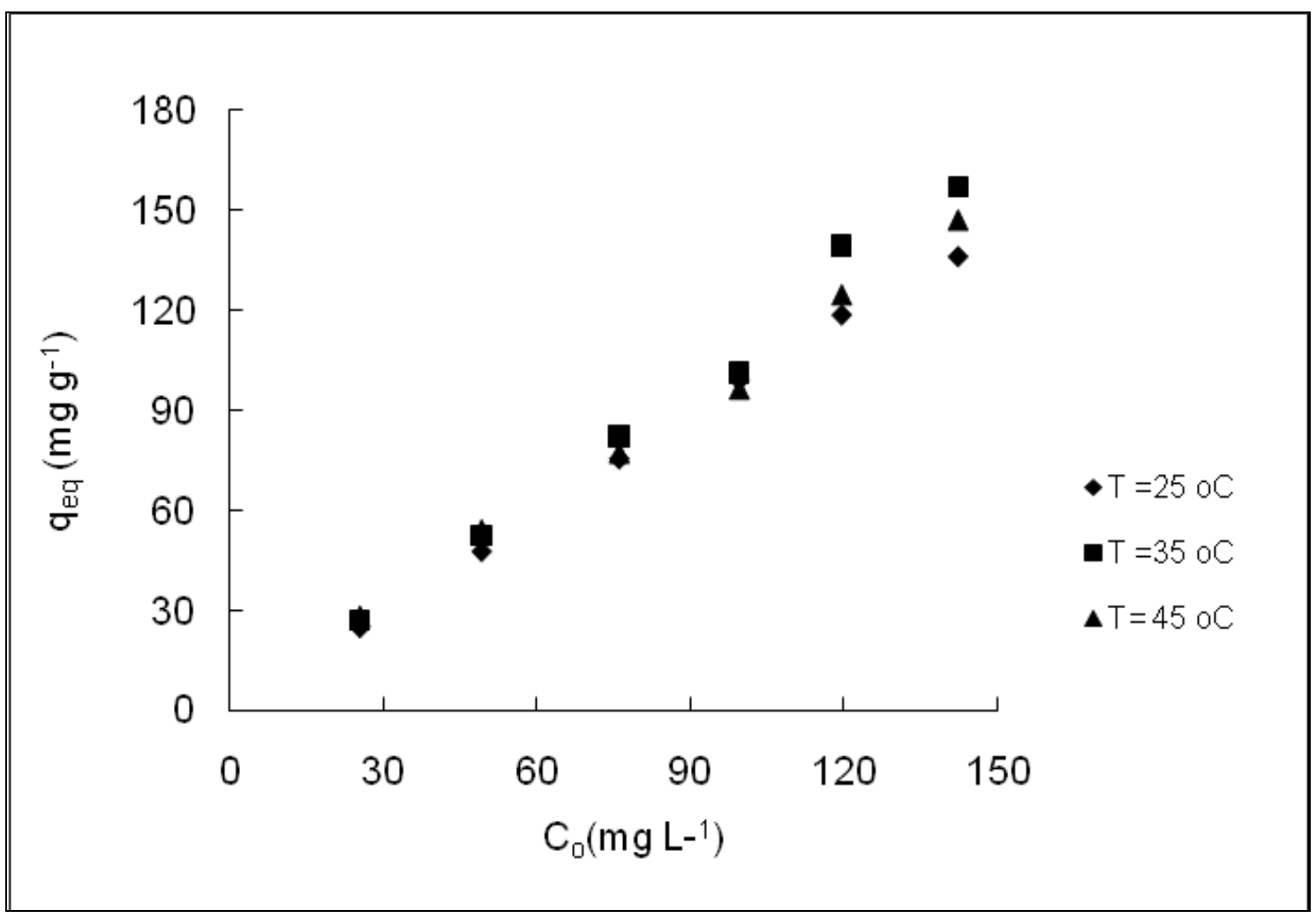

Figure 6. Experimental equilibrium data (non-linearized adsorption isotherms) of Procion Blue $M X-R$ obtained at 25,35 and $45^{\circ} \mathrm{C}$ ( $\mathrm{pH}$ 4.0, C=100 $\mathrm{mg} \mathrm{L}^{-1}$, agitation rate: $150 \mathrm{rpm}$ ).

Fig. 6 presents the experimental adsorption isotherm data of Procion MX-R on chitosan at three different temperatures. In the dye concentration range studied, the resulting isotherms 
were positive, regular, concave to the concentration axis, indicating an affinity for adsorption, and showed a saturation trend at higher dye concentrations; indicating a complete monolayer of dye covering the surface of adsorbent.

In order to analyze the experimental adsorption equilibrium data Langmuir and Freundlich adsorption isotherm graphs were obtained at the temperatures of 25,35 , and $45{ }^{\circ} \mathrm{C}$. Isotherm model constants and equilibrium monolayer capacities were given in Table 5. As it seen from the Table 5, the maximum monolayer capacities q of the adsorbent was determined as 113.33, 175.44 and $166.66 \mathrm{mg} \mathrm{g}^{-1}$ for 25,35 , and $45^{\circ} \mathrm{C}$ respectively. The results were proved that the best fit of equilibrium data in the Langmuir isotherm expression confirms the monolayer coverage of Procion MX-R dye onto chitosan. If it is compared the equilibrium capacities of chitosan with some adsorbent materials by various researches in the literature, we have seen that maximum equilibrium capasity values were determined as 645.1, 922.9, 973.33, 693.2, 728.2 $\mathrm{mg} \mathrm{g}^{-1}$ chitosan for Acid Green 25 (AG25), Acid Orange 10 (AO10), Acid Orange 12 (AO12), Acid Red 18 (AR18) and Acid Red 73 (AR73), respectively (Sakkayawong et al. 2005). Also, in the literature, the maximum monolayer capacity of mycelium pellets of Penicillium oxalicum is reported as $122 \mathrm{mg} \mathrm{g}^{-1}$ for Reactive Red 241 (RR241), $160 \mathrm{mg} \mathrm{g}^{-1}$ for Reactive Blue 19 (RB19) and $137 \mathrm{mg} \mathrm{g}^{-1}$ for Reactive Yellow 145(RY145) (Zhang et al. 2003).

Table 5. Langmuir and Freundlich adsorption constants of Procion Blue MX-R adosorption by chitosan at different temperatures.

\begin{tabular}{ccccccc}
\hline \multicolumn{3}{c}{ Langmuir Model } & \multicolumn{3}{c}{ Freundlich Model } \\
\hline $\mathrm{T}^{\circ} \mathrm{C}$ & $\mathrm{Q}^{\mathrm{o}}\left(\mathrm{mg} \mathrm{g}^{-1}\right)$ & $\mathrm{b}\left(\mathrm{L} \mathrm{g}^{-1}\right)$ & $\mathrm{R}^{2}$ & $\mathrm{~K}$ & $\mathrm{n}$ & $\mathrm{R}^{2}$ \\
25 & 113.33 & 0.70 & 0.985 & 52.0 & 2.04 & 0.944 \\
35 & 175.44 & 0.36 & 0.993 & 48.4 & 1.66 & 0.953 \\
45 & 166.66 & 0.17 & 0.988 & 38.1 & 1.62 & 0.912 \\
\hline
\end{tabular}

If we analyze the equilibrium data, we have seen that the Langmuir model represents the sorption data very well under the temperature and concentration ranges studied. The calculated corresponding linear regression correlation coefficient values $\left(\mathrm{R}^{2}\right)$ for Langmuir model were $>0.985$ at 25,35 , and $45^{\circ} \mathrm{C}$.

From the same Table, the correlation coefficient of linear Freundlich equation was $>0.912$. The magnitude of the Freundlich constants, indicated that the favourability and the capacity of the adsorbent/adsorbate system. If values of $n$ were $2<n<10$, this would be proved that adsorption is favourable. Similar results have been reported for adsorption of Orange G dye on chitosan (Wong et al. 2004), Methyl Violet adsorption on bottom ash (Gupta and Ali 2000), and perlite (Dogan andAlkan 2003). Values of $1 / \mathrm{n}$ less than 1 show the favourable nature of adsorption of OG and MV on BFA (Faust and Aly, 1987).

As it seen from Table 5, it can be resulted that the linear fits using the two equations were good for studying the adsorption of Procion MX-R dye onto chitosan within the used concentration range but the fit with the Langmuir equation was comparably better. Also, it was observed that the maximum adsorption capacity $\left(\mathrm{q}_{\mathrm{m}}\right)$ of chitosan for Procion MX-R dye was found to be $175.44 \mathrm{mg} \mathrm{g}^{-1}$. The best fit of equilibrium data in the Langmuir isotherm expression confirms the monolayer coverage of Procion MX-R dye onto chitosan. 


\section{Error Analysis}

In this investigation, in order to determine the best isotherm model that represents the adsorption isotherm data, three different error functions of non-linear regression basin were used.

\section{Marquardt's percent standard deviation (MPSD)}

Wong et al. (2004), Seidel\&Gelbin (1988) and Ng et al. (2003) previously used this error function (Eq. 4) in this field. MPSD function is reasonably similar in some aspects to a geometric mean error distribution moderated according to the number of degrees of freedom of the system (Marquardt, 1963)

$$
100 \sqrt{\frac{1}{p-n}}\left(\sum_{i=1}^{p}\left[\frac{\left(q_{e, \text { meas }}-q_{e, \text { calc }}\right)^{2}}{q_{e, \text { meas }}}\right]\right)^{1 / 2}
$$

\section{The average relative error (ARE)}

Kapoor et all., (1989) pointed out that this error function (Eq. 5) attempts to minimise the fractional error distribution across the entire concentration range.

$$
\frac{100}{n} \sum_{i=1}^{n}\left|\frac{q_{e, \text { calc }}-q_{e, \text { meas }}}{q_{e, \text { meas }}}\right|
$$

\section{The hybrid fractional error function (HYBRID)}

This error function (Eq. 6) was arranged so that the fit of the SSE method was improved at low concentration values by dividing by the measured value. Also a divisor was included as a term for the number of degrees of freedom for the system-the number of data points $n$ minus the number of parameters $\mathrm{p}$ within the isotherm equation (Porter et al., 1999).

$$
\frac{100}{n-p} \sum_{i=1}^{n}\left|\frac{q_{e, \text { calc }}-q_{e, \text { meas }}}{q_{e, \text { meas }}}\right|
$$

Since each of the error functions produce a different set of isotherm parameters, it is difficult to identify directly an overall optimum parameter set. Thus, a normalisation of each parameter is employed in order to have a better comparison between the parameter sets for the single isotherm model (Wong et al. 2004). In the normalisation processes first each error function was selected in turn and the results for each parameter set were determined. At the second stage, the errors determined for a given error function were divided by the maximum to obtain the normalised errors for each parameter set. Eventually, the normalised errors for each parameter set were summed.The values of all three error function (Hybrid, MPSD and Are) measurements were shown in Table 6. These values show that the Langmuir equation "best-follows" the 
equilibrium data for Procion MX-R adsorption on chitosan at $35^{\circ} \mathrm{C}$. This is same as predicted by $\mathrm{R}^{2}$ (non-linear) analysis (Table 5).

Table 6. Three different error analyses values of isotherm models for Procion Blue MX-R on chitosan at different temperatures.

\begin{tabular}{lccccccccc}
\hline \multicolumn{3}{c}{ HYBRID } & \multicolumn{3}{c}{ MPSD } & ARE \\
\hline & $\mathrm{T}=25$ & $\mathrm{~T}=35$ & $\mathrm{~T}=45$ & $\mathrm{~T}=25$ & $\mathrm{~T}=35$ & $\mathrm{~T}=45$ & $\mathrm{~T}=25$ & $\mathrm{~T}=35$ & $\mathrm{~T}=45$ \\
& ${ }^{0} \mathrm{C}$ & ${ }^{0} \mathrm{C}$ & ${ }^{0} \mathrm{C}$ & ${ }^{0} \mathrm{C}$ & ${ }^{0} \mathrm{C}$ & ${ }^{0} \mathrm{C}$ & ${ }^{0} \mathrm{C}$ & ${ }^{0} \mathrm{C}$ & ${ }^{0} \mathrm{C}$ \\
Langmuir & 32.54 & 15.09 & 37.20 & 28.76 & 16.05 & 32.55 & 21.70 & 10.38 & 24.80 \\
Freundlich & 5.94 & 0.91 & 13.35 & 14.47 & 18.11 & 19.14 & 9.57 & 12.18 & 14.74 \\
\hline
\end{tabular}

\section{Adsorption Kinetics}

In order to determine the behaviour of the adsorbent and also to examine the mechanism of solute adsorption onto an adsorbent and to test the experimental data, several kinetic models can be used. For the examination of the controlling mechanisms of adsorption process, such as chemical reaction, diffusion control and mass transfer, the adsorption data were analyzed using three kinetic models including pseudo-first order, pseudo-second order and the intraparticle diffusion models in this investigation.

In the literature, Lagergren presented the pseudo-first-order model which is called as the Lagergren's first-order reaction model (Lagergren et al., 1898). This model is expressed as follows:

$$
\mathrm{dq}_{\mathrm{t}} / \mathrm{dt}=\mathrm{k}_{\mathrm{f}}\left(\mathrm{q}_{\mathrm{e}}-\mathrm{q}_{\mathrm{t}}\right)
$$

where $\mathrm{q}_{\mathrm{t}}$ is the amount of adsorbent adsorbed at time $\mathrm{t}\left(\mathrm{mg} \mathrm{g}^{-1}\right), \mathrm{q}_{\mathrm{e}}$ is the adsorption capacity in equilibrium $\left(\mathrm{mg} \mathrm{g}^{-1}\right), \mathrm{k}_{\mathrm{f}}$ is the rate constant of pseudo-first-order kinetic model $\left(\mathrm{min}^{-1}\right)$, and $\mathrm{t}$ is the time ( $\mathrm{min})$.

By using definite integration based on applying the initial conditions $\mathrm{q}_{\mathrm{t}}=0$ at $\mathrm{t}=0$ and $\mathrm{q}_{\mathrm{t}}=\mathrm{q}_{\mathrm{t}}$ at $\mathrm{t}=\mathrm{t}$, the equation becomes

$$
\log \left(\mathrm{q}_{\mathrm{e}}-\mathrm{q}_{\mathrm{t}}\right)=\log \mathrm{q}_{\mathrm{e}}-\left(\mathrm{k}_{\mathrm{f}} / 2,303\right) \mathrm{t}
$$

The rate constant, $\mathrm{k}_{\mathrm{f}}$ was obtained from the slope of the linear plots of $\log \left(\mathrm{q}_{\mathrm{e}}-\mathrm{q}_{\mathrm{t}}\right)$ against $\mathrm{t}$.

In order to analyze the sorption data, pseudo-second order kinetic model which is proposed by Ho and McKay (1999) was used, too:

$$
\mathrm{dq} / \mathrm{dt}=\mathrm{k}_{\mathrm{s}}\left(\mathrm{q}_{\mathrm{e}}-\mathrm{q}_{\mathrm{t}}\right)^{2}
$$

where $\mathrm{k}_{\mathrm{s}}$ is the rate constant of pseudo-second-order model (in $\mathrm{g} \mathrm{mg}^{-1} \mathrm{~min}^{-1}$ ). After integration of Eq. (9) by using boundary conditions of $\mathrm{q}_{\mathrm{t}}=0$ at $\mathrm{t}=0$ and $\mathrm{q}_{\mathrm{t}}=\mathrm{q}_{\mathrm{t}}$ at $\mathrm{t}=\mathrm{t}$, the following equation can be obtained:

$$
\mathrm{t} / \mathrm{q}_{\mathrm{t}}=\left(1 / \mathrm{k}_{\mathrm{s}} \mathrm{q}_{\mathrm{e}}{ }^{2}\right)+\left(1 / \mathrm{q}_{\mathrm{e}}\right) \mathrm{t}
$$


The initial adsorption rate, $\mathrm{h}\left(\mathrm{mg} \mathrm{g}^{-1} \mathrm{~min}^{-1}\right)$ is defined as:

$$
\mathrm{h}=\mathrm{k}_{\mathrm{s}} \mathrm{q}_{\mathrm{e}}^{2}
$$

The initial adsorption rate $(\mathrm{h})$, the equilibrium adsorption capacity $\left(\mathrm{q}_{\mathrm{e}}\right)$, and the pseudosecond-order kinetic constant $\mathrm{k}_{\mathrm{s}}$ can be found experimentally from the slope and intercept of plot of $\mathrm{t} / \mathrm{q}_{\mathrm{t}}$ versus $\mathrm{t}$.

If there is the possibility of intraparticle diffusion being the rate-limiting step for the adsorption system, the intraparticle diffusion approach is used. This approach can be described by Weber and Morris (Weber and Morris, 1963).

$$
\mathrm{q}_{\mathrm{t}}=\mathrm{k}_{\mathrm{d}} \mathrm{t}^{1 / 2}+\mathrm{c}
$$

where $\mathrm{q}_{\mathrm{t}}$ is the amount of dye adsorbed $\left(\mathrm{mg} \mathrm{g}^{-1}\right)$ at time $\mathrm{t}, \mathrm{k}_{\mathrm{d}}\left(\mathrm{mg} \mathrm{g}^{-1} \min ^{-1}\right)$ is the rate constant for intraparticle diffusion, and $\mathrm{c}$ is the intercept.

The intraparticle diffusion model has three main steps. The first step is known as the external surface adsorption or boundary layer diffusion. The second step is the gradual stage of adsorption which is sometimes called as the intraparticle diffusion. In this model, if the plot of qt versus $t^{1 / 2}$ is linear and passes through the origin, then the intraparticle diffusion is the rate-controlling step. The last step is the final equilibrium stage in which the intraparticle diffusion starts to slow down due to the extremely low dye concentration left in the solution (Cheung et al., 2007).

In order to analyse the adsorption kinetic data of Procion MX-R, the pseudo-first-order, pseudo-second order, Weber and Morris models were applied to the experimental data.

Firstly, the linear form of the pseudo-first order model was examined. This model equation was given in Equation 8. The values of $\mathrm{k}_{\mathrm{f}}$ and $\mathrm{q}_{\mathrm{e}}$ were obtained from the slope and intercept respectively of plots of $\log \left(\mathrm{q}_{\mathrm{e}}-\mathrm{q}_{\mathrm{t}}\right)$ versus $\mathrm{t}$ (Fig. 7). It is clear from Table 7 that the calculated $\mathrm{q}_{\mathrm{e}}$ values did not agree with experimental $\mathrm{q}_{\mathrm{e}}$ values. So the pseudo-first order model did not fit well.

Table 7. First order reaction rate constants with experimental and calculated $q$ values obtained at different initial Procion Blue MX-R concentrations

\begin{tabular}{ccccc}
\hline $\mathrm{C}_{\mathrm{o}}\left(\mathrm{mg} \mathrm{L}^{-1}\right)$ & $\mathrm{q}_{\mathrm{e} e \text { exp }}\left(\mathrm{mg} \mathrm{g}^{-1}\right)$ & $\mathrm{k}_{\mathrm{f}}\left(\mathrm{g} \mathrm{mg}^{-1} \mathrm{~min}^{-1}\right)$ & $\mathrm{q}_{\mathrm{e}, \mathrm{cal}}\left(\mathrm{mg} \mathrm{g}^{-1}\right)$ & $\mathrm{R}^{2}$ \\
\hline 25 & 24.77 & 0.0821 & 21.57 & 0.906 \\
50 & 47.61 & 0.0661 & 31.48 & 0.964 \\
75 & 75.37 & 0.0835 & 41.20 & 0.962 \\
100 & 98.95 & 0.0589 & 52.80 & 0.970 \\
125 & 118.51 & 0.0589 & 61.21 & 0.972 \\
150 & 135.97 & 0.050 & 68.08 & 0.962 \\
\hline
\end{tabular}




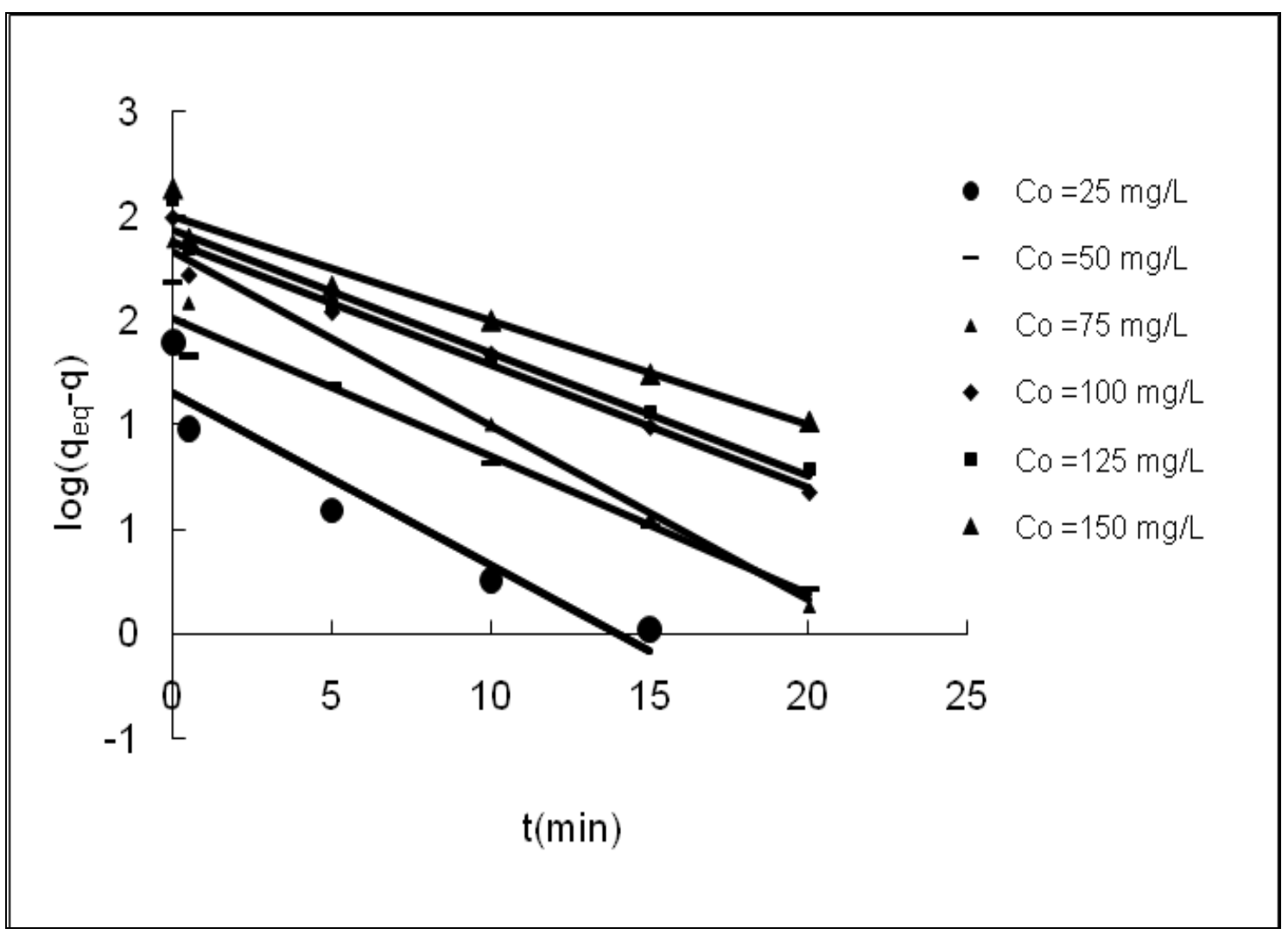

Figure. 7. Pseudo-first order kinetics for adsorption of Procion Blue $M X-R$ on chitosan ( $p H$ 4.0, $C=100 \mathrm{mg} \mathrm{L}^{-1}, X=1.0 \mathrm{~g} \mathrm{~L}^{-1} \mathrm{~T}=25^{\circ} \mathrm{C}$, agitation rate: $150 \mathrm{rpm}$ ).

The pseudo-second order model (Equation 10) also used to investigate the adsorption kinetics. The values of $\mathrm{k}_{\mathrm{s}}$ and $\mathrm{q}_{\mathrm{e}}$ can be determined experimentally from the slope and intercept of a plot of $\mathrm{t} / \mathrm{q}_{\mathrm{t}}$ versus $\mathrm{t}$ (Fig. 8). It is clear from Table 8 that the correlation coefficients $\mathrm{R}^{2}$ for the linear plots of the pseudo-second-order model was determined as 0.999. This value is higher than the correlation coefficients $\mathrm{R}^{2}$ for the pseudo first- order model. The calculated $\mathrm{q}_{\mathrm{e}}$ values are in agreement with experimental $\mathrm{q}_{\mathrm{e}}$ values. This proves that the pseudo-second-order model represent better the adsorption kinetic data.

Table 8. Second order reaction rate constants with experimental and calculated $q$ values obtained at different initial Procion Blue MX-R concentrations

\begin{tabular}{ccccc}
\hline $\mathrm{C}_{\mathrm{o}}\left(\mathrm{mg} \mathrm{L}^{-1}\right)$ & $\mathrm{q}_{\mathrm{e}, \text { exp }}\left(\mathrm{mg} \mathrm{g}^{-1}\right)$ & $\mathrm{k}_{\mathrm{S}}\left(\mathrm{g} \mathrm{mg}^{-1} \min ^{-1}\right)$ & $\mathrm{q}_{\mathrm{e}, \mathrm{cal}}\left(\mathrm{mg} \mathrm{g}^{-1}\right)$ & $\mathrm{R}^{2}$ \\
\hline 25 & 24.77 & 1.75 & 25.00 & 1.00 \\
50 & 47.61 & 0.81 & 48.54 & 0.990 \\
75 & 75.37 & 1.30 & 75.75 & 0.990 \\
100 & 98.95 & 0.69 & 100.00 & 0.999 \\
125 & 118.51 & 0.77 & 120.48 & 0.999 \\
150 & 135.97 & 0.51 & 142.85 & 0.999 \\
\hline
\end{tabular}




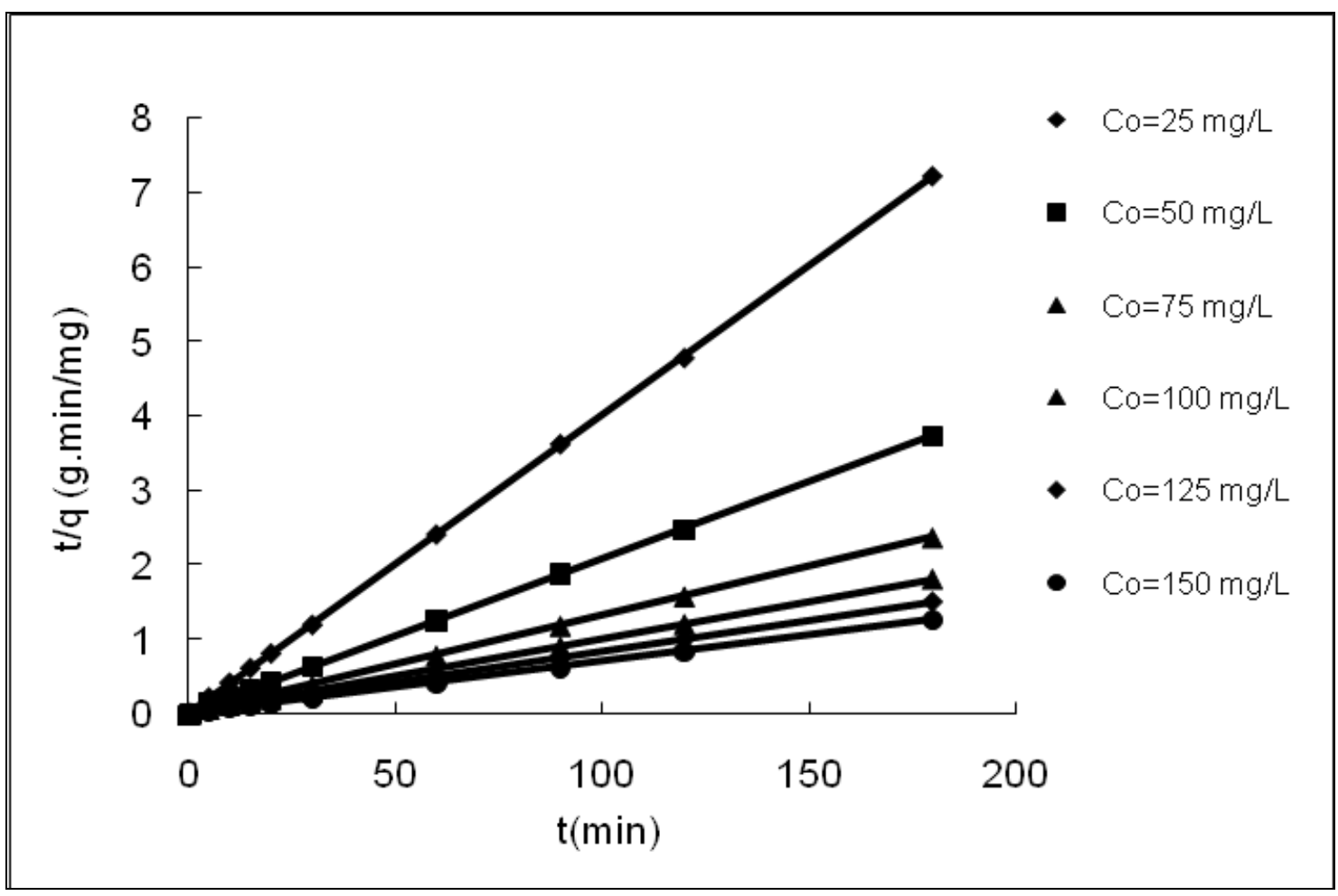

Figure. 8. Pseudo-second order kinetics for adsorption of Procion Blue MX-R on chitosan ( $p H$ 4.0, $C=100 \mathrm{mg} \mathrm{L}^{-1}, X=1.0 \mathrm{~g} \mathrm{~L}^{-1}, T=25^{\circ} \mathrm{C}$, agitation rate: $150 \mathrm{rpm}$ ).

Fig. 9 presents that the linear plot did not pass through the origin which indicated that the intraparticle diffusion was not the only the rate controlling step and the boundary layer diffusion controlled the adsorption to some degree (Cheung et al., 2007). Probably, this deviation may be the result of the difference in mass transfer rate in the initial and final stages of adsorption (Hameed and Hakimi, 2008).

The values of $\mathrm{C}$ and $\mathrm{k}_{\mathrm{d}}$ are shown in Table 9. The values of the intercept shown as " $\mathrm{C}$ " increased with an increase in initial Procion MX-R concentration $\left(25\right.$ to $\left.150 \mathrm{mg} \mathrm{L}^{-1}\right)$ which indicated an increasing boundary layer effect (Kannan and Sundaram, 2001).

Table 9. Intraparticle diffusion model constants and correlation coefficients for adsorption of Procion Blue MX-R on chitosan at $25^{\circ} \mathrm{C}$.

\begin{tabular}{ccccccc}
\hline $\mathrm{C}_{\mathrm{o}}\left(\mathrm{mg} \mathrm{L}^{-1}\right)$ & 25 & 50 & 75 & 100 & 125 & 150 \\
\hline $\mathrm{k}_{\mathrm{d}}$ & 2.4 & 5.57 & 9.94 & 13.08 & 17 & 18.18 \\
$\mathrm{C}$ & 14.47 & 21.88 & 32.401 & 36.33 & 40.57 & 46.53 \\
$\mathrm{R}^{2}$ & 0.927 & 0.969 & 0.973 & 0.994 & 0.978 & 0.994 \\
\hline
\end{tabular}

The corresponding linear plots of $\mathrm{q}_{\mathrm{e}}, \mathrm{k}_{\mathrm{s}}$ and $\mathrm{h}$ versus $\mathrm{C}_{0}$ were regressed to find expressions for these values in terms of the initial dye concentration with high correlation coefficients (Table 10). Therefore, it is useful for process design purposes if the terms $\mathrm{q}_{\mathrm{e}}, \mathrm{k}_{\mathrm{s}}$ and $\mathrm{h}$ can be defined as a function of $\mathrm{C}_{0}$ for the dye as follows (Ho and McKay, 1999): 


$$
\begin{aligned}
\mathrm{q}_{\mathrm{e}} & =\frac{\mathrm{C}_{0}}{\mathrm{~A}_{\mathrm{q} e} \mathrm{C}_{0}+\mathrm{B}_{\mathrm{qe}}} \\
\mathrm{k}_{2} & =\frac{\mathrm{C}_{0}}{\mathrm{~A}_{\mathrm{k} 2} \mathrm{C}_{0}+\mathrm{B}_{\mathrm{kn}}} \\
\mathrm{h} & =\frac{\mathrm{C}_{0}}{\mathrm{~A}_{\mathrm{h}} \mathrm{C}_{0}+\mathrm{B}_{\mathrm{h}}}
\end{aligned}
$$

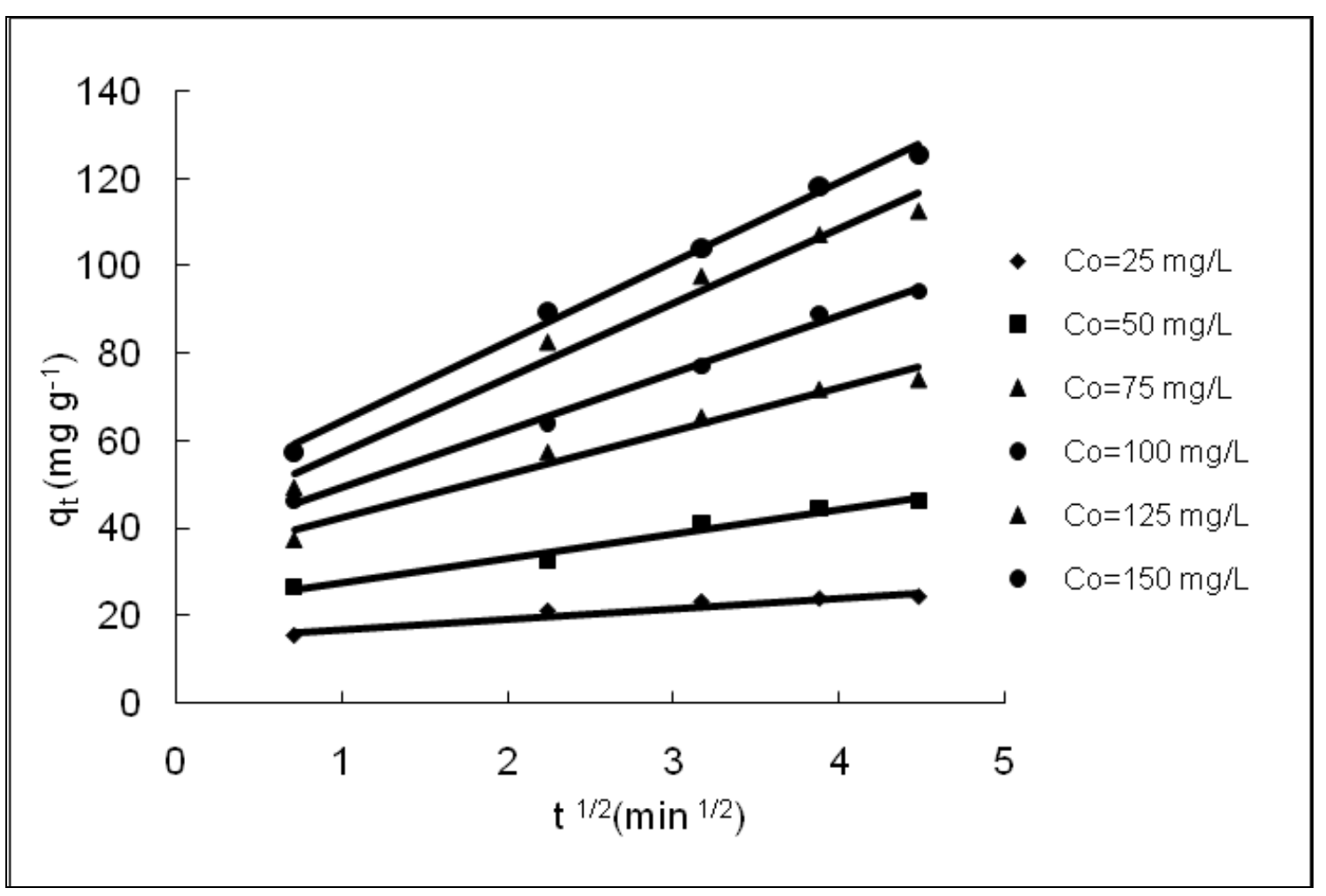

Figure. 9. Plot of intraparticle diffusion model for adsorption of Procion Blue MX-R on chitosan ( $\mathrm{pH} 4.0, \mathrm{C}=100 \mathrm{mg} \mathrm{L}^{-1}, X=1.0 \mathrm{~g} \mathrm{~L}^{-1}, T=25^{\circ} \mathrm{C}$, agitation rate: $150 \mathrm{rpm}$ ).

Table 10. Emprical parameters of predicted qe, $k 2$ and $h$ for Procion MX-R-chitosan system.

\begin{tabular}{lcccccc}
\hline $\begin{array}{l}\text { Concentration } \\
\text { range }\left(\mathrm{mg} \mathrm{L}^{-1}\right)\end{array}$ & $\mathrm{A}_{\mathrm{qe}}$ & $\mathrm{B}_{\mathrm{qe}}$ & $\mathrm{A}_{\mathrm{k} 2}$ & $\mathrm{~B}_{\mathrm{k} 2}$ & $\mathrm{~A}_{\mathrm{h} 2}$ & $\mathrm{~B}_{\mathrm{h} 2}$ \\
\hline $25-150$ & & & & & & \\
\end{tabular}

The rate law for pseudo-second order is obtained by substituting the values of $\mathrm{q}_{\mathrm{e}}$ from Table 8 into Eqs. (13)-(15) and then Eq. (10). Namely, the pseudo-second order rate law and the relationship of $\mathrm{q}, \mathrm{C}_{0}$ and $\mathrm{t}$ for chitosan can be presented in the following equations:

$$
\mathrm{q}=\frac{\mathrm{C}_{\mathrm{0}} \mathrm{t}}{\left(2.492 \times 10^{-4} \mathrm{C}_{0}+0.971\right) \mathrm{t}+1.254 \times 10^{-2} \mathrm{C}_{0}+0.264}
$$

Eq.16 is the generalized predictive model for the amount of Procion Blue MX-R dye adsorbed at any contact time and initial concentration within the given ranges. As it seen from 
this equation, the dye adsorbed at any contact time per unit mass is higher for a greater initial dye concentration.

\section{Adsorption Thermodynamics}

The amount of Procion MX-R dye adsorbed at different temperatures (298-318 K) has been examined to obtain thermodynamic parameters for the dye-chitosan adsorption system. For this purpose, the thermodynamic parameters of $\left(\Delta \mathrm{H}^{\circ}\right),\left(\Delta \mathrm{S}^{\circ}\right),\left(\Delta \mathrm{G}^{\circ}\right)$ were obtained by the slope and the intercept of the linear Van't Hoff plot between $\operatorname{lnK}_{\mathrm{c}}$ and $1 / \mathrm{T}$, respectively (Table 11). The negative values of $\Delta \mathrm{G}^{\circ}$ indicated the feasibility of the process and spontaneous nature of adsorption process. Also, the negative values of $\Delta \mathrm{H}^{\circ}$ obtained confirmed that Procion MX-R adsorption on chitosan process is an exothermic.

Table 11. Thermodynamic parameters for the adsorption of Procion Blue MX-R on chitosan

\begin{tabular}{|cc|ccc|}
\hline$\Delta \mathrm{S}^{\mathrm{o}}\left(\mathrm{kj} \mathrm{mol}^{-1} \mathrm{~K}^{-1}\right)$ & \multicolumn{3}{|c|}{$\Delta \mathrm{G}\left(\mathrm{kj} \mathrm{mol}^{-1}\right)$} \\
\hline \multirow{2}{*}{-0.1201} & -26.57 & $2 \mathrm{H}^{\circ}\left(\mathrm{kj} \mathrm{mol}^{-1} \mathrm{C}\right.$ & $35^{\circ} \mathrm{C}$ & $45^{\circ} \mathrm{C}$ \\
& & -8.745 & -9.47 & -9.91 \\
\hline
\end{tabular}

\section{SEM (Scanning Electron Microscopy)}

As it is known, scanning electron microscopy (SEM) is one of the most widely used surface diagnostic tools for characterizing the surface morphology and fundamental physical properties of the adsorbent surface. It is used to determine the particle shape, porosity and appropriate size distribution of the adsorbent. Scanning electron micrographs of raw chitosan and Procion MX-R adsorbed onto chitosan are shown in Fig. 10. From Fig. 10, it is obvious that chitosan has abundant numbers of pores where, there is a good potential for dyes to be trapped and adsorbed into these pores. The SEM of chitosan samples present very distinguished dark spots which can be taken as a sign for effective adsorption of Procion MX-R molecules in the cavities and pores of chitosan.

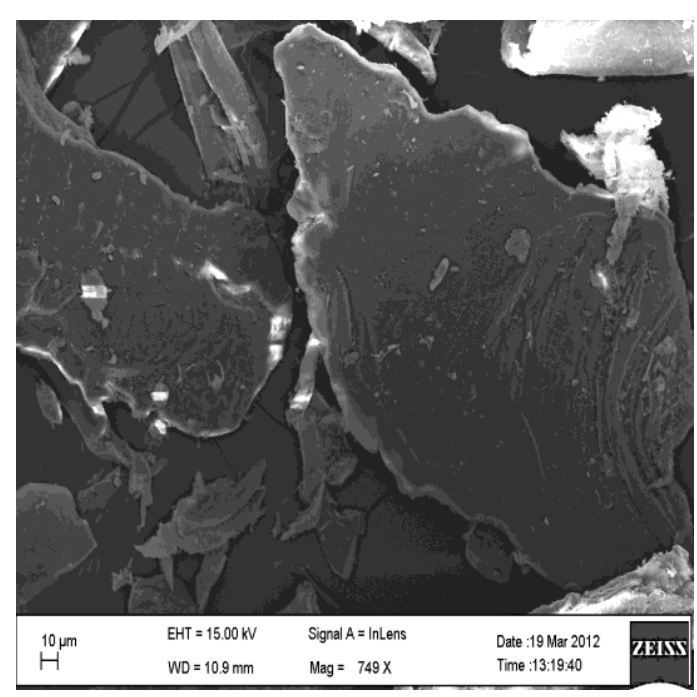

(a)

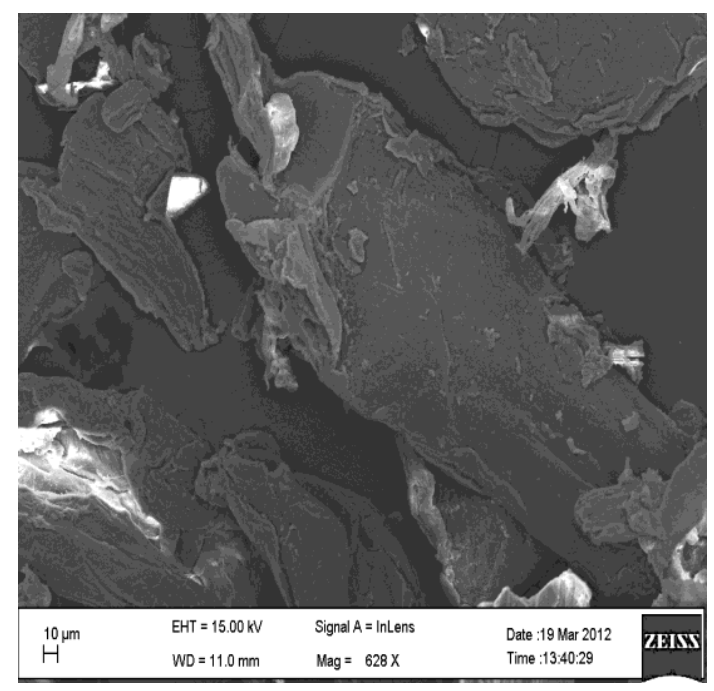

(b)

Figure. 10. Scanning electron microscopy images for: (a) original chitosan (b) chitosan adsorbed with Procion Blue MX-R 


\section{Conclusion}

In this study, the performance of the chitosan as an adsorbent to remove Procion Blue MX-R dye from SRDW have been investigated. The adsorption of Procion MX-R on chitosan was found to be strongly dependent on the solution $\mathrm{pH}$, initial dye concentration, adsorbent dose and temperature. The maximum removal was found at a $\mathrm{pH}$ of 4.0 and $35^{\circ} \mathrm{C}$. The adsorption capacities of the sorbent increase with increasing initial dye concentration. However, higher percentage of dye was removed with decrease in initial dye concentration for all temperatures studied. The adsorbate concentration on the adsorbent increased with a decrease in the adsorbent dose. The increasing temperature from 25 to $45^{\circ} \mathrm{C}$ decreased the adsorption capacity of chitosan. The experimental isotherm data were analysed using Langmuir and Freundlich isotherm models for the mathematical description of the adsorption equilibrium of dye on chitosan depending on temperature and the isotherm constants evaluated from the isotherms were used to compare the adsorptive capacity of chitosan. By comparing the correlation coefficients determined for each linear transformation of isotherm analysis, the Langmuir isotherm equation was found to provide the best prediction for Procion Blue MX-R dye sorption on chitosan. Also, the values obtained from three error functions showed that Langmuir isotherm had the lowest error values and thus fit the experimental data better than Freundlich isotherm at $35^{\circ} \mathrm{C}$. Assuming the batch adsorption as a single-staged equilibrium operation, it is possible to define the separation process mathematically by using these isotherm constants to predict the residual concentration of dye or amount of adsorbent for desired dye removal. An important factors for the process design and operation control are the adsorption process rate and dynamic behaviour of the system. The rate of diffusion may be restrictive in many practical applications. In order to investigate the adsorption mechanism, three simplified kinetic models, pseudo-first order, pseudo-second-order, and intra-particle diffusion were examined. A comparison of kinetic models on the overall adsorption rate showed that the dynamical adsorption behaviour of Procion Blue MX-R dye was described well by the pseudo-second-order model, while the intraparticle diffusion was not the only rate controlling step of the adsorption process. The adsorption data showed that external mass transfer, intraparticle diffusion and sorption process played an active role on dye adsorption by chitosan. It is clear that application of adsorption by chitosan in wastewater purification for the removal of Procion Blue MX-R from industrial wastewaters can be suitable for designing of wastewater treatment plants by using these kinetic parameters. Especially, it may be appropriate to apply such simple kinetic models to a well-agitated batch adsorption process.

At the end of the experimental study, thermodynamical parameters were also evaluated for the dye and revealed that the dye adsorption onto chitosan was a spontaneous, exothermic, and physical reaction.

The adsorption process of Procion Blue MX-R dye with chitosan hence considered to be a sustainable option for remediating dye-laden effluents. This study provides new insights about the removal of Procion Blue MX-R using chitosan, and our results could be further employed in the optimization and implementation of effective adsorption processes for treatment of wastewaters polluted by textile dye. We conclude that chitosan is very promising alternative adsorbent for color removal from industrial wastewater.

Further work needs now be geared towards upscaling the present findings and results into designing pilot-scale adsorption units. One of the important consideration for future 
research is the possibility of the use of this adsorbent in high yield with comparable effectiveness in treating a real industrial wastewater containing textile dye. In a laboratory scale, the dye wastewater is normally prepared synthetically with the content of the only single dye. However, real industrial wastewater consists of several dyes mixture, as well as other pollutants, such as ionic compounds. These dyes and ionic compound compete for the same adsorption sites on the adsorbent surfaces. Up to now, there are very few studies on the subject of real-world dye wastewater treatment. Certainly, more researchers should focused on the treatment of real-world textile dye wastewater using chitosan.

An adsorbent-regeneration methods is the another important consideration for future research. Regenaration is an improved process for the reuse of the adsorbent. To date, there are extremely few studies dedicated to the regeneration methods of chitosan are available and certainly more research is warranted. Clearly, more research efforts should be focused on developing regeneration methods that are more cost-effective than activated carbon regeneration, safer and environmentally friendly.

Acknowledgement.We thank Mersin University Scientific Research Projects Center (MEÜ BAP) with Grant No. BAP FBE KM (FÖ) 2012-1 YL for partial financial support.

\section{REFERENCES}

[1] Abbasi Z. and Alikarami, M. (2012):Kinetics and thermodynamics studies of acetic acid adsorption from aqueous solution by peels of banana.-Biochemistry and Bioinformatics, $1: 1-7$.

[2] Ali N., Hameed A. and Ahmed, S. (2009):Physicochemical characterization and Bioremediation perspective of textile effluent, dyes and metals by indigenous Bacteria.Journal of Hazardous Materials 164:322-328.

[3] Allen, S.J. (1987):Equilibrium adsorption isotherms for peat.- Fuel, 66:1171-1176.

[4] Allen., S.J., Mckay, G., Khader, K.Y.H. (1989):Intraparticle diffusion of a basic dye during adsorption onto sphagnum peat.- Environ. Pollut., 56:39-50.

[5] Alver, E. and Metin, A.Ü, (2012):Anionic dye removal from aqueous solutions usingmodified zeolite: Adsorption kinetics and isotherm studies.- Chemical Engineering Journal, 200: 59-67.

[6] Asfour, H.M., El-Geundi, M.S., Fadali, O.A., Nassar, M.M. (1985):Colour removal from textile effuents using hardwood sawdust as an adsorbent.- Chemical Tech. Biotech., 35A:28-35.

[7] Bailey, S.E., Olin, T.J., Bricka, R.M., Adrian, D.D. (1999):A review of potentially low cost sorbents for heavy metals.- Water Res., 33:2469-2479.

[8] Bousher, Shen, A.X., Edyvean, R.G.J. (1997):Removal of coloured organic matter by adsorption onto low-cost waste materials.- Water Res., 31:2084-2092.

[9] Bulut, Y., Aydin, H. (2006):A kinetics and thermodynamics study of methylene blue sorption on wheat shells.- Desalination, 194:259-267.

[10] Buthelezi, S. P., Olaniran, A.O., Pillay, B. (2012): Textile Dye Removal from Wastewater Effluents Using Bioflocculants Produced by Indigenous Bacterial Isolates.Molecules 17:14260-14274.

[11] Cheung, W.H., Szeto, Y.S., McKay, G. (2007):Intraparticle diffusion processes during acid Dye adsorption onto chitosan.- Bioresour Technol., 98:2897-2904.

[12] Crini, G. (2006): Non-conventional low-cost adsorbents for dye removal: a review.Bioresource Technology 97:1061-1085. 
[13] Doğan M. Alkan, M. (2003):Adsorption kinetics of methyl violet onto perlite.Chemosphere, , 50:517-528.

[14] El-Geundi, M.S. (1993):Pore diffusion model for the adsorption of basic dyestuffs onto natural clay in batch adsorbers.- Adsor. Sci. Technol., 9:109-120.

[15] El-Geundi, M.S. (1991):Homogenous surface diffusion model for the adsorption of basic dyestuff onto natural clay in batch adsorbers.- Adsor. Sci. Technol., 8:217-25.

[16] El-Geundi, M.S. (1990):External mass transport processes during the adsorption of basic dyestuffs onto Maize Cob.- Adsor Sci. Technol., 7:124.

[17] Epolito, W.J., Lee, Y.H., Bottomley, L.A. (2005):Characterization of the textile anthraquinone dye Reactive Blue 4.- Dyes Pigm., 67:35-46.

[18] Faust S.D. and Aly, O.M. (1987):Adsorption processes for water treatment, Butterworth,

[19] Fernanda, S.C.D.A., Eunice, F.S.V., Antonio, R.C. (2002):Interaction of indigo carmine dye with chitosan evaluated by adsorption and thermochemical data.- J. Colloid Interface Sci., 253:243-246.

[20] Freundlich, (1906):Hüber die adsorption in Losungen, Engelmann.

[21] Fu, F.L., Xiong, Y., Xie, B.P., Chen, R.M. (2007):Adsorption of Acid Red 73 on copper dithiocarbamate precipitate-type solid wastes.-Chemosphere, 66:1-7.

[22] Gupta, V.K., Ali, I. (2000):Utilisation of bagasse fly ash (a sugar industry waste) for the removal

[23] Garg, V.K Amita, M., Kumar, R., Gupta, R. (2004) :Basic dye (methylene blue) removal from simulated wastewater by sorption using Indian rosewood sawdust: a timber industry waste.- Dyes Pigments, 63:243-250.

[24] Garg, V.K., Kumar, R., Yadav, A.B., Gupta, R. (2003):Dye removal from aqueous solution by adsorption on treated sawdust.- Bioresour. Technol., 89:121-124.

[25] of copper and zinc from wastewater.- Sep. Purif. Technol., 18:131-140.

[26] Gupta, V.K. and Suhas. (2009):Application of low-cost adsorbents for dye removal-A review. -Journal of Environmental Management 90:2313-2342.

[27] Hameed, B.H. (2009): Removal of cationic dye from aqueous solution using jackfruit peel as non conventional low-cost sorbent.- J. Hazard. Mater., 162:344-350.

[28] Hameed, B.H., Hakimi, H. (2008):Utilization of durian (Durio zibethinus Murray) peel as low cost sorbent for the removal of acid dye from aqueous solutions.- Biochem. Eng. J., 39:338-343.

[29] Hariharasuthan, R., Rao, A.N. and Bhaskaran, A. (2013): Adsorption studies on reactiveblue 4 by varying the concentration of Mgo In Sorel's cement.- Adsorption, 2:287-292.

[30] Ho, Y.S., McKay, G. (1999):Comparative sorption kinetic studies of dye and aromatic compounds onto fly ash.- Sci. Health Part A, 34:1179-1204.

[31] Ho, Y.S., McKay, G. (1999):A kinetic study of dye sorption by biosorbent waste product.- pith Res., Conserv. Recycl., 25:171-193.

[32] Kannan, N., Sundaram, M.M. (2001):Kinetics and mechanism of removal of methylene blue by adsorption on various carbons-a comparative study.- Dyes Pigments, 51:25-40.

[33] Kapoor, A., Yang, R.T. (1989):Correlation of equilibrium adsorption data of condensible vapours on porous adsorbents.- Gas Separation \& Purification, 3:187-192.

[34] Kobya, M., Demirbaş, E., Şenturk, E., \& Ince, M. (2005): Adsorption of heavy metalions from aqueous solutions by activated carbon prepared from apricot Stone.-Bioresource Technology, 96:1518-1521.

[35] Lagergren, S., Vetenskapsakademiens, K. S. (1898):Zur theorie der Sogenannten Adsorption Gelöster Stoffe Kungliga Svenska Vetenskapsakademiens.-Handlingar, 24:139.

[36] Langmuir, I. (1918):The adsorption of gases on plane surfaces of glass mica and platinum.- J. Am. Chem. Soc., 40:1361-1403.

[37] Lin, S.H., Lo, C.C. (1996):Treatment of textile wastewater by foam flotation.- Environ Technol., 17:841-849. 
[38] Lopez-Grimau, V., Gutierrez, M.C. (2006):Decolourisation of simulated reactive dyebath effluents by electrochemical oxidation assisted by UV light.-Chemosphere, 62:106-112.

[39] Magdy, Y.H. (1996):The adsorption of mixed dyes onto hardwood in fixed bed.- Adsor. Sci. Technol., 13:367.

[40] Malik, P.K. (2003):Use of activated carbons prepared from sawdust and rice-husk for adsorption of acid dyes: a case study of acid yellow 36.- Dyes Pigments, 56:239-249.

[41] Mall, I.D., Upadhyay, S.N. (1998):Studies on treatment of basic dyes bearing wastewater by adsorptive treatment using fly ash.- Ind. J. Environ. Health., 40:177-188.

[42] Mall, I.D., Upadhyay, S.N., Sharma, Y.C. (1996):A review on economical treatment of wastewaters and effluents by adsorption.- Int. J. Environ. Stud., 51:77-124.

[43] Mall, I.D., Upadhyay, S.N. (1995):Treatment of methyl violet bearing wastewater from paper mill effluent using low cost adsorbents.- J. Indian Pulp Paper Technol. Assoc., 7:51-57.

[44] Mall, I.D., Upadhyay, S.N. (1995):Removal of basic dyes from wastewater using boiler bottom ash.- Ind. J. Environ. Health, 37:1-10.

[45] Marquardt, W.J. (1963):An algorithm for least-squares estimation of nonlinear parameters.- Soc. Ind. Appl. Math., 11:431-441.

[46] McClung, S.M., Lemley, A.T. (1994):Electrochemical treatment and HPLC analysis of wastewater containing acid dyes.- Text Chem Color, 26:17-22.

[47] McKay, G. (1982):Adsorption of dyestuffs from aqueous solutions with activated carbon I: equilibrium and batch contact-time studies.-J. Chem. Technol. Biotechnol, 32:759772.

[48] McKay, G. Blair, H.S., Gardner, J.R. (1982):Adsorption of dyes on chitin. I, Equilibrium studies.- J. Appl. Polym. Sci., 27:3043-3057.

[49] Mckay, G., El-Geundi, M., Nassar, M.M. (1987):Equilibrium studies during the removal of dye stuffs from aqueous solutions using bagasse pith.- Water Res., 21:15131520.

[50] Mckay, G., El-Geundi, M., Nassar, M.M., (1988):External mass transport process during the adsorption of dyes onto bagasse pith.- Water Res., 22:1527-1533.

[51] Muzzarelli, R.A.A., Boudrant, J., Meyer, D., Manno, N., DeMarchis, M., and Paoletti, M. G. (2012):Current views on fungal chitin/chitosan, human chitinases, food preservation,glucans, pectins and inulin: A tribute to Henri Braconnot, precursor of the carbohydrate polymers science, on the chitin bicentennial.- Carbohydrate Polymers, 87:995-1012.

[52] Nassar, M.M., Ashour, E.A., Magdy, Y.H. 1996:Dye adsorbent bagasse, a new potential source for energy conversion Proceedings of the fifth international conference on energy and environment, Cairo, Egypt, 993-1001.

[53] Namasivayam, C., Kavitha, D. (2002):Removal of congo red from water by adsorption onto activated carbon prepared from coir pith, an agricultural solid waste.- Dyes Pigments, 54:47-58.

[54] Namasivayam, C., Kanchana, N. (1992):Waste banana pith as adsorbent for colour removal from wastewaters.- Chemosphere., 25:1691-1705.

[55] Namasivayam, C., Kanchana, N., Yamuna, R.T. (1993):Waste banana pith as adsorbent for the removal of rhodamine-B from aqueous solution.-Waste Manag., 13:89-95.

[56] Namasivayam, C., Kadirvelu, K., Kumuthu, M. (1998):Removal of direct red and acid brilliant blue by adsorption on to banana pith.- Bioresource Technol., 64:77-79.

[57] Namasivayam, C., Kumar, M., Dinesh, Selvi, K., Begum, A., Vanathi, T., Yamuna, R.T. (2001):Waste coir pith-a potential biomass for the treatment of dyeing wastewaters.Biomass Bioenergy, 21:477-483.

[58] Namasivayam, C., Arasi, D.J.S.E. (1997):Removal of congo red from wastewater by adsorption onto waste red mud.- Chemosphere, 34:401-417. 
[59] Namasivayam, C., Muniasamy, N., Gayathri, K., Rani, M., Ranganathan, K. (1996):Removal of dyes from aqueous solutions by cellulosic waste orange peel.Bioresour. Technol., 57:37-43.

[60] Namasivayam, C., Yamuna, R.T. (1992):Removal of congo red from aqueous solutions by biogas waste slurry.- J. Chem. Technol. Biotechnol., 53:153-157.

[61] Namasivayam, C., Yamuna, R.T. (1992):Removal of Rhodamine B by biogas residual slurry from aqueous solution.- Water Air Soil Pollut., 65.101-109.

[62] Ng, J.C.Y., Cheung, W.H., McKay, G. (2003):Equilibrium studies for the sorption of lead from effluents using chitosan.-Chemosphere, 52:1021-1030.

[63] Oakes, J., Gratton, P. (1998): Kinetic investigations of the oxidation of arylazonaphthol dyes in hypochlorite solutions as a function of pH.- J Chem Soc Perkin Trans., 2:22012206.

[64] Papic, S., Koprivanac, N., Loncaric Bozic, A. (2000):Removal of reactive dyes from wastewater using Fe(III) coagulant.- J. Soc. Dyers Color, 116:352-358.

[65] Pollard, S.J.T., Fowler, G.D., Sollars, C.J., Perry, R. (1992):Low-cost adsorbents for waste and wastewater wastewater treatment: a review.- Sci. Total Environ., 116:31-52.

[66] Poots, V.J.P., McKay, G., Healy, J.J. (1978):Removal of basic dye from effluent using wood as an adsorbent.- J. Water Pollut. Control. Fed., 50:926-939.

[67] Poots, V.J.P., Mckay, G., Healy, J.J. (1976):The removal of acid dye from effluent using natural adsorbents I-peat.- Water Res., 10: 1061-1066.

[68] Porter, J.F., McKay, G., Choy, K.H. (1999):The prediction of sorption from a binary mixture of acidic dyes using single and mixed isotherm variants of the ideal adsorbed solute theory.- Chem. Eng. Sci., 54:5863-5885.

[69] Poulios, I., Aetopoulou, I. (1999):Photocatalytic degradation of the textile dye Reactive Orange 16 in the presence of TiO suspensions.-Environ Technol., 20:479-487.

[70] Sakkayawong, N., Thiravetyan, P., Nakbanpot, W. (2005):Adsorption mechanism of synthetic reactive dye wastewater by chitosan.- Journal of Colloid and Interface Science, 286:36-42.

[71] Seidel, A., Gelbin, D. (1988):On applying the ideal Adsorbed Solution Theory to Multicomponent Adsorption Equilibria of Dissolved Organic Compounds on Actiated Carbon., Chem. Eng. Sci., 43:79-89.

[72] Swamy, M.M., Mall, I.D., Prasad, B. Mishra, I.M. (1998):Sorption characteristics of Ocresol on bagasse fly ash and activated carbon.- Ind. J Environ. Health., 40:67-78.

[73] Tahir, S.S., Rauf, N. (2006): Removal of a cationic dye from aqueous solutions by adsorption onto bentonite clay.-Chemosphere, 63:1842-1848.

[74] Uzun, I., Guzel, F. (2004):Kinetics and thermodynamics of the adsorption of some dyestuffs and $\mathrm{p}$-nitrophenol by chitosan and MCMchitosan from aqueous solution.- $\mathbf{J}$. Colloid Interface Sci., 274:398-412.

[75] Weber, W.J., Morris, J.C. (1963):Kinetics of adsorption on carbon from solution.- J. Sanit. Engg. Div., 89:31-60.

[76] Wong, Y.C., Szeto, Y.S., Cheung, W.H., McKay, G. (2004):Adsorption of acid dyes on chitosan e equilibrium isotherm analyses.- Process Biochem., 39:693-702.

[77] Yadla, S.V., Sridevi, V., Chandana, M. and Lakshmi, V.V. (2012):Adsorption performance of fly ash for the removal of lead.- International Journal of Engineering Research \& Technology, 1.

[78] Yehia, H.M., Abd El-Hakim, A.M. J. (1997):Adsorption of dyestuffs from aqueous solutions using bean-waste I. External mass transfer processes.- Egypt Soc. Eng., 36:44.

[79] Zhang, J., Yang, M., Yang, Q.X., Xin, B.P., Pan, F. (2003):Biosorption of reactive dyes by the mycelium pellets of a new isolate of Penicillium oxalicum.- Biotechnol Lett., 25:1479-1482. 